\title{
1 Hyperaccumulators of metal and metalloid trace 2 elements: facts and fiction
}

3

4 Antony van der Ent, Centre for Mined Land Rehabilitation, Sustainable Minerals

5 Institute, The University of Queensland, Australia*

6

7 Alan J. M. Baker, School of Botany, The University of Melbourne and Centre for 8 Contaminant Geoscience, Environmental Earth Sciences International Pty Ltd, Australia 9
Roger D. Reeves, Palmerston North, New Zealand

A. Joseph Pollard, Department of Biology, Furman University, Greenville, South Carolina, USA

Henk Schat, Department of Genetics, Molecular and Cellular Biology, Vrije Universiteit, Amsterdam, The Netherlands

\section{Corresponding author:}

CMLR. The University of Queensland, St Lucia. QLD 4072, Australia.

Email: a.vanderent@uq.edu.au Tel: +61 (0) 413436685 


\section{BACKGROUND}

Plants that accumulate metal and metalloid trace elements to extraordinarily high concentrations in their living biomass have inspired much research worldwide during the last decades. Hyperaccumulators have been recorded and experimentally confirmed for elements such as nickel, zinc, cadmium, manganese, arsenic and selenium. However, to date, hyperaccumulation of lead, copper, cobalt, chromium and thallium remain largely unconfirmed. Recent uses of the term in relation to rare-earth elements require critical evaluation.

\section{SCOPE}

34 Since the mid-1970s the term 'hyperaccumulator' has been used millions of times by thousands of people, with varying degrees of precision, aptness and understanding that have not always corresponded with the views of the originators of the terminology and of the present authors. There is therefore a need to clarify the circumstances in which the term 'hyperaccumulator' is appropriate and to set out the conditions that should be met when the terms are used. We outline here the main considerations for establishing metal or metalloid hyperaccumulation status of plants, (re)define some of the terminology and note potential pitfalls.

42

\section{CONCLUSIONS}

44 Unambiguous communication will require the international scientific community to adopt standard terminology and methods for confirming the reliability of analytical data.

Keywords: Hyperaccumulator, metallophyte, trace elements, metal, metalloid, hydroponic experiments. phytoextraction.

\section{Introduction}

The term 'hyperaccumulator' was devised by one of the present authors (Reeves) as part of the title of a paper reporting the extraordinary accumulation of nickel by the tree Sebertia acuminata (now Pycnandra acuminata) in New Caledonia (Jaffré et al. 1976; Swenson and Munzinger 2010). The term 'hyperaccumulation' can be found in Brooks et al. (1977) and in many subsequent publications, being used to describe accumulation of $\mathrm{Ni}$ to $>1,000 \mu \mathrm{g} / \mathrm{g}$ in dry leaf tissue. This level was chosen as being 100-1,000 times higher than that normally found in plants on soils not of ultramafic origin, and 10-100 times higher than that found for most other plants on Ni-rich ultramafic soils. Although there was some arbitrariness in the choice of this criterion, it was noted that in many ultramafic floras, Ni concentrations of $100-1,000 \mu \mathrm{g} / \mathrm{g}$ are quite rare, and accumulation to 
$62>1,000 \mu \mathrm{g} / \mathrm{g}$ seems to represent a distinct form of plant response, implying some

63 characteristic and unusual metabolic functionalities.

65 An attempt to give greater precision to the definition of Ni hyperaccumulation was made 66 by Reeves (1992) for $\mathrm{Ni}$ : "a hyperaccumulator of $\mathrm{Ni}$ is a plant in which a $\mathrm{Ni}$

67 concentration of at least $1,000 \mu \mathrm{g} / \mathrm{g}$ has been recorded in the dry matter of any above68 ground tissue in at least one specimen growing in its natural habitat". This indicates that 69 the use of the term should not be based on analyses of whole plants or subterranean plant 70 parts, (i) because of the difficulty of ensuring that the samples are free of soil 71 contamination, and (ii) because plants that immobilize metals in the root system are 72 relatively common, whereas active accumulation in above-ground tissues is more 73 diagnostic of hyperaccumulation (Baker 1981; Baker et al. 1994b). To make the original 74 definition even more precise, above-ground tissue should be regarded as plant leaves only 75 for establishing hyperaccumulator status, and it is also important to note that the criterion 76 for hyperaccumulation is thereby thus set at the organ level (leaves), and not at the level 77 of specific tissues or organelles (e.g. epidermis) or the latex. Furthermore 'accumulation' 78 should imply only active accumulation inside the plant leaf tissue, via the roots; passive 79 accumulation via air-borne deposition on plant leaves is not to be considered when 80 (hyper)accumulation is discussed.

This more detailed definition is also intended to clarify questions surrounding cases 83 where (1) some specimens of a species may be found with $>1,000 \mu \mathrm{g} / \mathrm{g}$ and others with $84<1,000 \mu \mathrm{g} / \mathrm{g}$, or (2) a species has been found to take up high levels of a metal under 85 artificial conditions, such as through substantial metal-salt amendments to an 86 experimental soil or a nutrient solution. Plants would qualify as hyperaccumulators under case (1) but not under (2). Concentrations of metals can greatly differ between plant parts; in some plants metal concentrations in the xylem or latex are many times those in the leaf. Examples include Sebertia acuminata with $257,400 \mu \mathrm{g} / \mathrm{g}$ in latex and 11,700 $\mu \mathrm{g} / \mathrm{g}$ in leaves (Jaffré et al. 1976) and Phyllanthus balgooyi with 90,000 $\mu \mathrm{g} / \mathrm{g}$ in the phloem tissues and 16,000 $\mu \mathrm{g} / \mathrm{g}$ in leaves (Hoffmann et al. 2003). It appears to be very unusual, however, for a plant to reach hyperaccumulator threshold concentrations in other organs or the latex/sap, but not in leaves. The implication of the phrase 'growing in its natural habitat' is that hyperaccumulators must achieve their high metal concentrations while remaining healthy enough to maintain a self-sustaining population.

Subsequent to its original publication, the terminology of hyperaccumulation has been expanded to elements other than Ni. A comprehensive discussion of the early reports on unusual accumulation of $\mathrm{Zn}, \mathrm{Cd}, \mathrm{Pb}, \mathrm{Co}, \mathrm{Cu}, \mathrm{Mn}, \mathrm{Cr}$ and $\mathrm{Se}$ is given in the review by 101 Reeves (2005). As the interest in plants accumulating these elements developed, the 
102 concepts and definitions of hyperaccumulation have been extended. Malaisse et al. 103 (1978) used the $1,000 \mu \mathrm{g} / \mathrm{g}$ criterion for $\mathrm{Cu}$ accumulation, and Brooks et al. (1980) 104 argued for this to be applied also to Co. Reeves and Brooks (1983b) used the same 105 criterion in discussing $\mathrm{Pb}$, but for $\mathrm{Mn}$ and $\mathrm{Zn}$, which are normally present at higher and 106 more widely varying concentrations (about 20-400 $\mu \mathrm{g} / \mathrm{g}$ ), a 10,000- $\mu \mathrm{g} / \mathrm{g}$ threshold was 107 suggested by Baker and Brooks (1989), following the use of the term 108 'hypermanganèsophore' for plants with this level of Mn accumulation (Jaffré 1980). 109 Normal Cd levels are so low $(0.03-5.0 \mu \mathrm{g} / \mathrm{g}$ in most plant species) that those plants 110 capable of concentrating this element to $>100 \mu \mathrm{g} / \mathrm{g}$ should be regarded as $\mathrm{Cd}$ 111 hyperaccumulators (Baker et al. 1994a), having significant phytoremediation potential.

We consider accumulation of major soil elements ( $\mathrm{Fe}, \mathrm{Ca}, \mathrm{Mg}, \mathrm{Na}$ and $\mathrm{Al}$ ) to constitute a 114 different phenomenon to hyperaccumulation of trace elements, and do not discuss these further here (for a discussion of Al accumulation see Metali et al. 2012).

\section{The basis for hyperaccumulation threshold criteria}

The metal supply to a plant ranges from deficiency to optimum and eventual toxicity, and differs greatly between elements, being particularly narrow for transition metals such as $\mathrm{Zn}, \mathrm{Cu}$ and $\mathrm{Ni}$ (Clemens et al. 2002). When a species establishes on a soil with either a too low or a too high metal supply, adjustments will take place within the limits of phenotypic plasticity followed by adaptation and evolution of efficiency or tolerance in populations over time (Schat 1999; Pollard et al. 2002; Ernst 2006,). The uptake and metabolism of non-essential metals and metalloids (e.g. Cd, As, Pb) is not regulated as tightly as for essential metals (e.g. $\mathrm{Zn}, \mathrm{Cu}$ ) because of interference or lack of specificity of the ecophysiology of plants (Ernst 2006). There have been efforts to define typical concentrations of metals and metalloids in plants, and the worldwide 'standard reference plant' has elemental concentrations ( $\mu \mathrm{g} / \mathrm{g})$ of $\mathrm{Ni}(1.5), \mathrm{Zn}(50), \mathrm{Cd}(0.05), \mathrm{Pb}(1), \mathrm{Cu}$ (10), Co (0.2), Cr (1.5), Mn (200), Tl (0.02), As (0.1) and Se (0.02) (Markert 1994; Dunn 2007).

The hyperaccumulation threshold criterion for $\mathrm{Ni}$ was not only chosen because it is 101,000 -fold higher than the average concentration of that element in plant leaves but also because $1,000 \mu \mathrm{g} / \mathrm{g}$ seemed to separate two modes of a bimodal frequency curve (Brooks and Radford 1978; Brooks et al. 1979). These frequency curves showed more or less lognormally distributed concentrations up to about $1,000 \mu \mathrm{g} / \mathrm{g}$ and an outlying cluster at exceptionally high concentrations. This bimodal pattern is particularly apparent in phylogenetically restricted data sets, such as in the genus Alyssum in the Brassicaceae (Brooks 1987, 1998; Pollard et al. 2002). Such bimodality has also been found in some edaphically limited datasets of plants growing on ultramafic soils, such as a dataset from 
142 temperate ultramafic plants which showed a sharp discontinuity, but not in a dataset with 143 tropical ultramafic plants which showed an approximate lognormal distribution (Reeves 144 1992; Reeves et al. 2007).

146 Further (meta)analysis for a range of metals (Broadley et al. 2001; Watanabe et al. 2007)

147 has dealt with accumulation of elements in plants, but do not clarify whether 148 hyperaccumulators form a qualitatively distinct group (a bimodal pattern), which would 149 indicate a different physiology, or whether hyperaccumulators are merely the tail of a 150 positively skewed continuous (lognormal) distribution. Such datasets are not suitable for 151 defining hyperaccumulation criteria because of the relative rarity of hyperaccumulators, 152 making it statistically difficult to distinguish between bimodality and skewness. This is 153 exemplified by the approximately 23,000 species within the Asterales, of which only 38 154 are hyperaccumulators under the current criteria (Broadley et al. 2001). Only datasets 155 limited phylogenetically or edaphically (e.g. from metalliferous soils) could be of use in 156 this respect. For phylogenetically limited datasets, there are however few candidates 157 other then the genus Alyssum. On a global scale the genera Phyllanthus and Psychotria 158 are some of the largest for Ni hyperaccumulators, but compared to the overall size of 159 these huge genera the hyperaccumulators will still be a minority. On the other hand, the 160 genus Buxus in Cuba has $17 \mathrm{Ni}$ hyperaccumulators and 17 non-accumulators (Reeves et 161 al. 1996), showing distinct bimodality. Much will thus depend on the selection of the 162 genera and the geographical delimitation. Edaphically limited datasets may be 163 inappropriate for statistical recognition of hyperaccumulators because of various forms of 164 sampling bias, e.g. a specific search for new hyperaccumulators. This means that 165 providing statistical evidence for a qualitatively distinct group and basing thresholds on 166 the group delimitation is extremely difficult.

168 Other criteria, not based upon nominal threshold values, could be considered to define 169 hyperaccumulation. In particular, hyperaccumulators have a very high bioconcentration 170 factor (shoot:soil ratio) as a result of their physiological make-up enabling active metal 171 sequestration and concentration, and it has been suggested that this should be a critical 172 factor in recognition of hyperaccumuators (Hobbs and Streit 1986). However, the 173 bioconcentration factor in isolation cannot serve as a definition of hyperaccumulation 174 when based on field-collected material, because it is manifested as a genotype $\times$ 175 environment interaction and is controlled by both the genetically-determined physiology 176 of the plants and the local edaphic conditions (Pollard et al. 2002). Hyperaccumulators 177 can sequester metals even from soils with low metal concentrations; for example, some 178 populations of Thlaspi caerulescens and Arabidopsis halleri growing on normal soils still 179 exhibit hyperaccumulation (Reeves et al. 2001; Bert et al. 2002; Assunção et al. 2003). 180 As such there is no unequivocal relationship between leaf metal content and the total 181 metal concentration in the soil or its bioavailability, which is a characteristic feature of 
182 hyperaccumulators (Baker 1981). A complicating factor is that no chemical extraction 183 method (including $\mathrm{CaCl}_{2}$, DTPA, EDTA, ammonium acetate) universally and accurately 184 replicates the bioavailable soil metal fraction for hyperaccumulators, although advances 185 are made with more realistic approaches e.g. carboxylic acid extraction (Feng et al. 2005) 186 and in better replicating the soil-rhizosphere interface e.g. Diffusive Gradients in Thin 187 films; DGT (Zhang et al. 2004; Tandy et al. 2011; Watanabe et al. 2011). Even if an ideal 188 soil extraction method could be formulated, the logic of the shoot:soil ratio is 189 questionable. Metal concentrations in plants are measured on a dry-weight basis and are 190 thus, to a good approximation, a ratio of metal mass to cellulose mass. Soil 191 measurements, however, are a ratio of metal mass to the solid fraction of the soil. As the 192 denominators of these ratios are totally different, it is not apparent why they should be 193 directly comparable. Moreover, high soil metal concentrations could result in a 194 bioconcentration factor < 1, for example in ultramafic soils with 3,000 $\mu \mathrm{g} / \mathrm{g} \mathrm{Ni}$ in the soil 195 and $2,000 \mu \mathrm{g} / \mathrm{g}$ in a plant (while such a plant would clearly have an abnormal 196 physiology), or conversely plants growing on soils deficient in essential trace elements 197 (e.g Zn) might be extremely efficient in sequestration and hence have very high 198 bioconcentration factors yet low absolute concentrations. The bioconcentration factor 199 however might have use in a comparative way, when growing plants in homogenized soil 200 or in hydroponic culture but this has little advantage over simple comparisons of foliar 201 metal concentrations.

Another criterion sometimes proposed for defining hyperaccumulation is the shoot-toroot quotient of metal concentrations (or translocation ratio), which typically is $>1$ in hyperaccumulators (Macnair 2003). While a useful property in supporting other evidence of hyperaccumulation, this ratio cannot be used alone to define hyperaccumulation for several reasons: (i) the difficulty of sampling roots from many plants, especially trees; (ii) the difficulty in analysis of ensuring that roots are free of all soil contamination and externally sorbed metal ions; (iii) the fact that the relative concentrations on a dry weight basis of a metal in various plant organs (leaves, roots, stems, fruits, seeds, etc.) may depend as much on the proportion of structural material in those tissues as on the detailed solution transport processes; (iv) a plant with, for example, $10 \mu \mathrm{g} / \mathrm{g}$ metal in the root and $20 \mu \mathrm{g} / \mathrm{g}$ in the leaves, while having a translocation ratio $>1$, is of no special importance in the context of hyperaccumulation; (v) metal partitioning into shoots relative to the roots may depend on external metal supply (Talke et al. 2006) and the higher root-to-shoot biomass ratio of some hyperaccumulators can also contribute to relatively high shoot-toroot metal quotients (Krämer et al. 1997).

In contrast to these attempts to define hyperaccumulation on statistical grounds, the 'Holy 220 Grail' (Baker and Whiting 2002) would be an over-arching, 'physiological definition' of 221 hyperaccumulation, based on structural, functional, or metabolic characters unique to 
hyperaccumulators. Knowledge of the physiology and genetics of hyperaccumulation has been greatly advanced in recent years (Pence et al. 2000; Talke et al. 2006; Courbot et al. 2007; Willems et al. 2007; Hanikenne et al. 2008; Richau et al. 2009). However, the inherent complexities of the phenomenon, such as the specificity for different metals (Zhao et al. 2002; Assunção et al. 2003) and the array of different physiologies enabling hyperaccumulation (Van de Mortel et al. 2006; Richau et al. 2009) make a workable physiological definition still far away.

As a workable approach, we propose to set hyperaccumulation threshold criteria at a level that is (i) 2-3 orders of magnitude higher than in plant leaves on normal soils, and (ii) at least one order of magnitude greater than the usual range in plant leaves on metalliferous soils. However, nominal thresholds should be applied sensibly and not regarded as a 'magical' or absolute cut-off, e.g. a plant that consistently accumulates $900 \mu \mathrm{g} / \mathrm{g}$ Ni still exhibits extreme physiological behaviour, and should therefore be regarded as a hyperaccumulator of that metal. As such, nominal threshold criteria are part of an operational framework, complemented with a suite of characteristics which include (a) a bioconcentration factor $>1$ (but often >50); (b) a shoot-to-root metal concentration quotient $>1$ and (c) extreme metal tolerance ('hypertolerance') due to effective biochemical detoxification (Baker and Whiting 2002).

\section{Patterns of hyperaccumulation in natural populations}

Hyperaccumulators can be further categorized according to the consistency of their metal accumulation behaviour. We distinguish here between 'obligate' (also called 'strict') and 'facultative' hyperaccumulators. The obligate hyperaccumulator species are endemic to some type of metalliferous soil and always exhibit metal uptake at the level defined for hyperaccumulation. Facultative hyperaccumulators, on the other hand, are species with populations of which (some) individuals are hyperaccumulators and other individuals of the same species are not (Pollard et al. 2002). Facultative hyperaccumulation can result from (i) genetic differences between different (separated) populations of a species; or (ii) soil-based differences, i.e. differences in metal ion availability and uptake. The latter can result from variations in (1) the total concentration in the soil of the element of interest;

254 (2) the presence of the metal in different phases or chemical forms; (3) differences in soil $\mathrm{pH}$; (4) the concentrations of major elements in the soil; (5) physical factors, such as the

256 local rainfall, soil porosity and evaporation characteristics. Facultative 257 hyperaccumulation applies when the species or at least a local population possesses the 258 inherent propensity for metal accumulation and the local soil factors provide sufficient 259 metal availability. The frequency of occurrence of different facultative 260 hyperaccumulators on metalliferous vs. normal soils varies: some species occur 261 predominantly on metalliferous soils, while others occur predominantly on normal soils. 
The facultative hyperaccumulator category covers a variety of situations. It includes particularly those species that occur on both metalliferous and non-metalliferous (normal) soils, showing hyperaccumulation from only the metalliferous ones. On normal soils, such plants do not hyperaccumulate, either because they cannot do so because of a genetic difference, or (more generally) because of the low availability of the metal in question.

Leaf analysis of the widespread Rinorea bengalensis, for example, includes 23 specimens showing $\mathrm{Ni}$ concentrations of 1,000-17,750 $\mu \mathrm{g} / \mathrm{g}$ from ultramafic soils, and another 77 specimens with 1-300 $\mu \mathrm{g} / \mathrm{g}$ from other soils (Brooks and Wither 1977; Reeves unpublished) and is hence a typical facultative hyperaccumulator. There are more complex cases however, for example the Australian Pimelea leptospermoides that is apparently restricted to Ni-rich ultramafic soils, but shows a wide range of $\mathrm{Ni}$ concentrations (15-2,800 $\mu \mathrm{g} / \mathrm{g}$ ) from those soils (Reeves unpublished). Some species are able to hyperaccumulate from soils with low metal content, for example Thlaspi (Noccaea) caerulescens that has been found on various localities (e.g. sites in Luxembourg, France, Spain, Scotland and Sweden) with very high Zn concentrations on soil with low Zn status (Reeves et al. 2001; Assunção et al. 2003).

\section{Nickel}

300 As indicated in the introduction to this paper, nickel was the first element designated as

301 being hyperaccumulated by plants. Nickel hyperaccumulators comprise the great 
majority of the current reports of hyperaccumulation, and there is broad agreement that $1,000 \mu \mathrm{g} / \mathrm{g}$ represents a useful criterion for their recognition. Various additional terms have been used to indicate other levels of $\mathrm{Ni}$ accumulation. Brooks et al. (1977) described the small number of plants in their study that showed 100-1,000 $\mu \mathrm{g} / \mathrm{g} \mathrm{Ni}$ as 'strong accumulators', and at the highest end of the scale, Jaffré and Schmid (1974) used the term 'hypernickelophores' for plants with $>10,000 \mu \mathrm{g} / \mathrm{g}(1 \%)$ in the dry matter. It is doubtful whether these additional categories are required. Certainly those species regularly showing more than $1 \% \mathrm{Ni}$ are good candidates for applications such as phytoremediation and phytomining, but they seem to form part of a continuum that begins around $1,000 \mu \mathrm{g} / \mathrm{g}$.

\section{Zinc}

Zinc hyperaccumulation is also well-established as occurring in natural populations (Reeves and Brooks 1983a; Reeves 1988; Escarré et al. 2000) and well-studied in experimental systems (Shen et al. 1997). Reeves and Baker (2000) suggested that the $10,000 \mu \mathrm{g} / \mathrm{g}$ criterion of Baker and Brooks (1989) might in some cases be regarded as unduly restrictive. In particular, for $\mathrm{Zn}$, present in most plants on zinc-rich soils at 50-500 $\mu \mathrm{g} / \mathrm{g}$, it might be more appropriate to regard Zn levels above 3,000 $\mu \mathrm{g} / \mathrm{g}$ as remarkable, and deserving of being described as hyperaccumulation. An example is Gomphrena canescens from Australia with 9,000 $\mu \mathrm{g} / \mathrm{g} \mathrm{Zn}$ (Cole et al. 1968). Furthermore, some very strongly Zn-accumulating species might then not be described as non-accumulators, a term used by Shen et al. (1997) for Thlaspi ochroleucum, which can be found with up to 6,300 $\mu \mathrm{g} / \mathrm{g} \mathrm{Zn}$ and 5-100 $\mu \mathrm{g} / \mathrm{g}$ Cd on zinc-rich soils (Reeves 1988 and unpublished), as well as $5,200 \mu \mathrm{g} / \mathrm{g} \mathrm{Ni}$ on ultramafic soils (Reeves 1988). The lower criterion for $\mathrm{Zn}$ was also proposed by Broadley et al. (2007) and Krämer (2010). For phytoremediation potential, and also for biological reasons $(3,000 \mu \mathrm{g} / \mathrm{g} \mathrm{Zn}$ is more than enough to suggest 'abnormal physiology'), there is likely to be interest in any species that consistently shows such $\mathrm{Zn}$ levels, particularly if Cd levels are also abnormally high.

\section{Cadmium}

Work in several laboratories from about 1994 onwards has revealed the Cdhyperaccumulating ability of Thlaspi (Noccaea) caerulescens (Robinson et al. 1998; Escarré et al. 2000; Lombi et al. 2000, 2001b; Reeves et al. 2001) and Arabidopsis halleri (Bert et al. 2002, 2003). The genetic propensity for Cd hyperaccumulation varies strongly between populations (Lombi et al. 2001b; Assunção et al. 2003; Bert et al. 2003; Roosens et al. 2003). More recently, several Cd hyperaccumulators have been described from China, notably Rorippa globulosa (Sun et al. 2007), Solanum nigrum (Wei et al. 2006; Gao et al. 2010), Sedum alfredii (Deng et al. 2008) and Viola baoshanensis (Liu et al. 2004; $\mathrm{Li}$ et al. 2010). We note that much of the research with Cd hyperaccumulators from this region, and some reports of 'new hyperaccumulators' are based on hydroponic 
experiments with artificial exposure to $\mathrm{Cd}$. However, some of these cases of $\mathrm{Cd}$

343 hyperaccumulation do exist under natural conditions (Wang et al. 2009; Wu et al. 2010).

344 Almost all natural Cd-rich soils (e.g. calamine soils mineralised with $\mathrm{Zn}-\mathrm{Pb}-\mathrm{Cd}$ ) are also

345 extremely enriched in $\mathrm{Zn}$. Cadmium hyperaccumulators must therefore also be very $\mathrm{Zn}$ -

346 tolerant in their natural habitats, and hence Zn-toxicity in effect limits Cd-

347 hyperaccumulation. For example, Arabis paniculata from China can accumulate 20,800

$348 \mu \mathrm{g} / \mathrm{g}$ Zn as well as $2,300 \mu \mathrm{g} / \mathrm{g} \mathrm{Pb}$, and $434 \mu \mathrm{g} / \mathrm{g} \mathrm{Cd}$ (Tang et al. 2009). Caution should

349 however be exercised when putative Cd-hyperaccumulators are grown in soils amended

350 only with $\mathrm{Cd}$. This stresses again that hyperaccumulators have to be recorded from the

351 natural habitats and exemplifies the importance of using natural soils in experiments.

\section{Lead}

354 There are several reports of $\mathrm{Pb}$ concentrations above $1,000 \mu \mathrm{g} / \mathrm{g}$ in plant material, using material collected directly from the field (Johnston and Proctor 1977; Williams et al. 1977; Barry and Clark 1978; Deram and Petit 1997; Rotkittikhun et al. 2006) or supplied by herbaria (Reeves and Brooks 1983b). It is certainly true that some species such as Thlaspi (Noccaea) caerulescens can accumulate $\mathrm{Pb}$ in shoots to levels of the order of 300 $\mu \mathrm{g} / \mathrm{g}$ from $\mathrm{Pb}$-amended nutrient solution, whilst immobilizing $\mathrm{Pb}$ in the roots at levels close to 30,000 $\mu \mathrm{g} / \mathrm{g}$ (Baker et al. 1994b). Recent experiments have shown that some populations of T. caerulescens from southern France can accumulate $\mathrm{Pb}$ at $>1,000 \mu \mathrm{g} / \mathrm{g}$ in leaf dry matter in nature, as well as from nutrient solution amended with low molar concentrations of $\mathrm{Pb}$ (Mohtadi et al. 2012). Similar reports have been made from Thailand where 26 taxa collected from a lead mine area were shown to accumulate foliar lead to these levels (Rotkittikhun et al. 2006).

Much higher foliar concentrations can be achieved with the use of Pb-complexing and mobilizing agents such as EDTA and EDDS ('induced phytoextraction' sensu Salt et al. 1998), as shown in work on Brassica juncea and B. carinata grown in hydroponic solution or in EDTA-treated soil (Kumar et al. 1995; Vassil et al. 1998). As noted above, we do not regard extreme accumulation achieved through hydroponics or chemicallyamended soils as hyperaccumulation. Brassica juncea has no specific uptake mechanisms for $\mathrm{Pb}$ and part of the enhanced uptake results from damage to the root membrane by EDTA (Vassil et al. 1998). Moreover, such in situ chelate-induced phytoextraction introduces serious environmental problems and is cost prohibitive for large-scale application (Chaney et al. 2007). The chelating agents used to induce in situ phytoextraction cause $\mathrm{Pb}$ to become mobile and leach out and contaminate groundwater and surrounding soils, a pollution scenario that is nearly impossible to control. At the optimal concentration in the soil solution these chelating agents (EDTA) are also very expensive (Chaney et al. 2002). Although much recent scientific inquiry has focused on reducing the risks of the technology, by searching for chelating agents that are more 

contamination issues largely remain (Ro $\square$ mkens et al. 2001; Wu et al 2004; Nowack et

384 al. 2006).

The high values recorded in material grown naturally have always been from the vicinity of $\mathrm{Zn} / \mathrm{Pb}$ mine sites or smelters. Here, there has invariably been a local long-term exposure to metals from the surface expression of underlying geological sources. Under these conditions there is abundant opportunity for contamination by wind-blown or rainsplashed dusts and soil, or even (in the case of smelters) from vapour-phase deposition. We regard the existing records as doubtful, and requiring further confirmation through the use of samples that have been treated to remove surface contamination. Rigorous washing with de-ionized water or a detergent solution are effective methods to clean the surface of roots and leaves from particulates (McLaughlin et al. 1985; Azcue 1996). Such washing may not remove metals that are fully enclosed by wax, however, which requires intensive washings with non-polar solvents in order to remove all cuticular metals, but this may in turn damage the underlying tissue and release metals from the internal structure. Where intensive treatment with non-polar wax-dissolving agents (e.g. hexane) in an ultrasonic bath does not significantly decrease the foliar metal concentration, then hyperaccumulator status can be affirmed, but when such washings decrease foliar metal concentrations it is still unknown whether the metal arrived in the cuticle via the air or via the roots. In Thlaspi caerulescens metal accumulation in the cuticle can also occur in metal-free air (Schat unpublished), which makes hexane washing problematic.

Accurate mass calculations comparing the leaf $\mathrm{Pb}$ with the total soil $\mathrm{Pb}$ can give an estimate of potential $\mathrm{Pb}$ contamination, but an option to exclude surface contamination with $\mathrm{Pb}$ and other metals from the analysis is to grow the plants from seed in their natural soil in the glasshouse or a climate room, where aerial deposition can be entirely precluded. Such controlled experiments are necessary in any instance where surface contamination is suspected, except when foliar metal concentrations are far in excess of the total soil concentrations (which is often not the case for mine tailings and smelter sites). In addition, an experiment to distinguish between $\mathrm{Pb}$ entering the plant via the root system and that deposited externally, using two soils of very different $\mathrm{Pb}$ isotopic composition, has been devised by Reeves et al. (2005); the experiment itself has not yet been conducted.

\section{Copper and cobalt}

Copper hyperaccumulators have been recorded from the DR Congo (with at least 32 species; Reeves and Baker 2000; Reeves 2005) and also from China, with species such as Elsholtzia splendens (E. haichowensis) (Jiang et al. 2004) and Commelina communis (Wang et al. 2004). There are also five records $>1,000 \mu \mathrm{g} / \mathrm{g} \mathrm{Cu}$ from Sri Lanka, which 
422 includes Geniosporum tenuiflorum with 2,299 $\mu \mathrm{g} / \mathrm{g}$ (Rajakaruna and Baker 2006) and 423 from Salajar Island (Indonesia) with seven records $>300 \mu \mathrm{g} / \mathrm{g} \mathrm{Cu}$, up to $600 \mu \mathrm{g} / \mathrm{g}$ in 424 Laportea ruderalis (Brooks et al. 1978). The evidence for copper hyperaccumulation is, 425 however, limited and most of the copper hyperaccumulators that have been described 426 from the DR Congo (Malaisse et al. 1978; Brooks et al. 1982; Leteinturier 2002) could 427 not be verified in a recent study which employed intensive washing of the plant leaf 428 material (Faucon et al. 2007). The authors of this study found that 12 species that were 429 studied and which were previously recorded as copper hyperaccumulators did indeed 430 have high copper concentrations, but rarely exceeded the limit for hyperaccumulation. 431 They concluded that the large variation of plant concentrations within a single site, 432 significant linear soil/plant correlation (pointing to 'bioindicator' behaviour) and 433 relatively low concentrations in many specimens are uncharacteristic for 434 hyperaccumulators. It seems that most of the earlier analytical results were contaminated 435 by dust. For example, $0.2 \mathrm{mg}$ of malachite included as a dust with $100 \mathrm{mg}$ of plant leaf 436 genuinely containing $10 \mu \mathrm{g} / \mathrm{g} \mathrm{Cu}$ is enough to raise the apparent $\mathrm{Cu}$ concentration to more than $1,150 \mu \mathrm{g} / \mathrm{g}$ (Reeves and Baker 2000).

$\mathrm{Cu}$ concentrations in plant leaves are controlled within a narrow range $(\approx 10 \mu \mathrm{g} / \mathrm{g})$ even on metalliferous soils, and regardless of the difficulties in obtaining contamination-free plant leaves, the current hyperaccumulator criterion for copper is probably too high (Faucon et al. 2007). This relates also to the current situation with cobalt hyperaccumulators. Cobalt concentrations are normally very low in plant leaves $(0.03-2$ $\mu \mathrm{g} / \mathrm{g}$ ) and even on metalliferous soils seldom reach $20 \mu \mathrm{g} / \mathrm{g}$. Cobalt hyperaccumulators are predominantly known from the DR Congo. In addition, Co reaches 530-845 $\mu \mathrm{g} / \mathrm{g}$ in Nyssa sylvatica on non-metalliferous soils in the US (Kubota et al. 1960; Brooks et al. 1977; Robinson et al. 1999). There are two records of Phyllanthus species from Cuba and

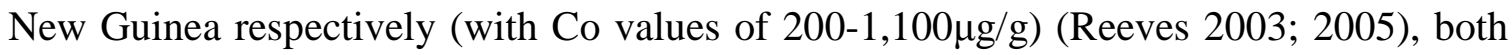
from ultramafic soils. It is important to note that in ultramafic soils Ni might limit Cohyperaccumulation, because $\mathrm{Ni}$ is usually present in concentrations 10-fold greater than those of Co (Malik et al. 2000). Krämer (2010) proposed to lower the hyperaccumulation criteria for $\mathrm{Co}$ and $\mathrm{Cu}$ to $300 \mu \mathrm{g} / \mathrm{g}$, and we affirm this.

455 Chromium hyperaccumulation is another phenomenon for which evidence is mostly 456 lacking. In soils chromium generally has very low plant availability, and thus low 457 potential uptake (Han et al. 2004), although in New Caledonia (Becquer et al. 2003) and 458 Brazil (Garnier et al. 2006) relatively high available chromium (VI) has been reported, 459 which could cause phytotoxicity. Examples where chromium hyperaccumulation has 460 been described include Leersia hexandra (Zhang et al. 2007) and Spartina argentinensis 461 (Redondo-Gómez et al. 2010). However, chromium values differed greatly between sites 
and plants; this might indicate surface contamination and/or the inability to remove surface contamination during analysis, which, as with copper, might cause spurious results. Given the very low chromium concentrations in plants, both on normal $(<1 \mu \mathrm{g} / \mathrm{g})$ and metalliferous (ultramafic) soils ( $<50 \mu \mathrm{g} / \mathrm{g}$ ), it is proposed to set the criterion at 300 $\mu \mathrm{g} / \mathrm{g}$ for hyperaccumulator status.

Thallium

469 Currently only a small number of thallium hyperaccumulators have been reported, all from Southern France: Biscutella laevigata with with up to 15,200 $\mu \mathrm{g} / \mathrm{g}$ Tl (Anderson et al. 1999), Iberis intermedia with up to $2,810 \mu \mathrm{g} / \mathrm{g}$ Tl (LaCoste et al. 1999, Leblanc et al. 1999) and Silene latifolia with up to $1,489 \mu \mathrm{g} / \mathrm{g}$ (Escarré et al. 2011). Various authors have proposed threshold hyperaccumulation concentrations of either $500 \mu \mathrm{g} / \mathrm{g}$ (Leblanc et al. 1999) or 1,000 $\mu \mathrm{g} / \mathrm{g}$ (McGrath 1998; Krämer 2010), without discussion or justification of why these values were selected. Further study is required to validate these reports and designate appropriate criteria, but given that $\mathrm{Tl}$ concentrations are generally $<0.02 \mu \mathrm{g} / \mathrm{g}$ in plant leaves, we propose a tentative threshold value of $100 \mu \mathrm{g} / \mathrm{g}$.

\section{Manganese} and Brooks 1989; Fernando et al. 2009; Pollard et al. 2009). As mentioned above, the criterion for Mn hyperaccumulation is $10,000 \mu \mathrm{g} / \mathrm{g}$, reflecting the general abundance of this element in soils and biological materials (Baker and Brooks 1989). The majority of Mn hyperaccumulators are from ultramafic soils, such as in several species in the genus Gossia (Myrtaceae) from Australia with up to 21,500 $\mu \mathrm{g} / \mathrm{g}$ Mn (Fernando et al. 2009) and a number of $\mathrm{Mn}$ hyperaccumulators from New Caledonia including Macadamia neurophylla with up to $51,800 \mu \mathrm{g} / \mathrm{g}$ Mn (Jaffré 1979) and Maytenus spp. with up to 32,000 $\mu \mathrm{g} / \mathrm{g}$ Mn (Jaffré 1977; Fernando et al. 2008). Hyperaccumulation of Mn has also been reported in Phytolacca spp. from industrially-polluted soils (Xue et al. 2004), and it appears that the phenomenon also occurs on naturally-occurring soils derived from manganiferous schist (Pollard unpublished).

494 The Se content of soils is usually $0.01-2 \mu \mathrm{g} / \mathrm{g}$, but can greatly exceed this range, reaching concentrations of several hundred $\mu \mathrm{g} / \mathrm{g}$ in soils derived from certain Cretaceous shales (Reeves 2005). Recognition that some plants contain exceptionally high concentrations of selenium has a long history, pre-dating the origin of hyperaccumulator terminology (Rosenfeld and Beath 1964; Terry et al. 2000). The recent literature is particularly rich in reports on the ecological significance of selenium hyperaccumulation in natural populations (Barillas et al. 2011). Most authors regard $1000 \mu \mathrm{g} / \mathrm{g}$ as a criterion for Se hyperaccumulation. However, because normal Se levels in plants are below $2 \mu \mathrm{g} / \mathrm{g}$, a 
502 case could be made for considering any plant with more than $100 \mu \mathrm{g} / \mathrm{g}$ as a 503 hyperaccumulator of this element. Selenium hyperaccumulators are widespread in the US 504 and Australia where they occur on Se-rich shale with about $10 \mu \mathrm{g} / \mathrm{g}$ Se (Reeves and 505 Baker 2000). Most Se hyperaccumulators are in the families of Fabaceae such as the 506 genus Astralagus, including Astragalus bisulcatus and the Brassicaceae including 507 Stanleya pinnata, both these species hyperaccumulate up to $10,000 \mu \mathrm{g} / \mathrm{g}$ Se (Freeman et 508 al. 2006).

510 Hyperaccumulation of As, defined as a concentration above $1,000 \mu \mathrm{g} / \mathrm{g}$, has been 511 reported in ferns growing on industrially polluted soils, with further reports from 512 laboratory screening (reviewed in Reeves 2005). Arsenic hyperaccumulation has been 513 described for a number of Pteris spp., most notably Pteris vittata with up to $22,630 \mu \mathrm{g} / \mathrm{g}$ 514 As (Ma et al. 2001; Wang et al. 2007) and other ferns such as Pityrogramma calomelanos 515 with up to $8,350 \mu \mathrm{g} / \mathrm{g}$ As (Visoottiviseth et al. 2002). Because of the toxicity of As, this 516 phenomenon has been intensively studied for its potential in phytoremediation. Arsenic 517 also occurs in some aquatic species exposed to naturally elevated As concentrations in 518 the water. The relatively frequent occurrence of As hyperaccumulation among 519 hydrophytes (as opposed to terrestrial plants) is largely due to precipitation of water520 borne As on or in the peripheral cell walls of the leaf, rather than 'active uptake' across 521 the plasma membrane (Robinson et al. 2006). This is comparable with terrestrial plants 522 trapping airborne contamination (see issues with supposed $\mathrm{Pb}, \mathrm{Co}, \mathrm{Cu}, \mathrm{Cr}$ 523 hyperaccumulation), especially those species growing in environments polluted by 524 human activities.

\section{Rare earth elements}

Reports have appeared recently on the accumulation of light rare earth elements (LREEs) such as cerium (Ce) and lanthanum (La), predominantly from China (Shan et al. 2003; Wei et al. 2005; Lai et al. 2006; Wang et al. 2006). An example is Dicropteris dichotoma, which accumulates up to 7,000 $\mu \mathrm{g} / \mathrm{g}$ LREEs in its dry leaf biomass (Shan et al. 2003) and Pronephrium simplex with up to 3,000 $\mu \mathrm{g} / \mathrm{g}$ LREEs (Lai et al. 2006). Little is known about the ecophysiological functions of LREEs or appropriate criteria for defining their hyperaccumulation. The reported hyperaccumulators have been described from industrial smelter sites, available for plant colonization only recently, and more information is needed to establish the routes of uptake of the elements into the plants. Again airborne contamination might be a factor here. Until more is known about the behaviour of LREEs in plants, hyperaccumulator criteria cannot be set.

\section{Numbers of hyperaccumulators}


541 As explained above, we propose to set hyperaccumulation threshold criteria at a 542 minimum of 2-3 orders of magnitude higher than foliar concentrations on normal soils, 543 and at least one order of magnitude greater than the range in foliar concentrations on 544 metalliferous soils. On this basis, we recommend the following concentration criteria for 545 different metals and metalloids in dried foliage: $100 \mu \mathrm{g} / \mathrm{g}$ for $\mathrm{Cd}$, Se and $\mathrm{Tl} ; 300 \mu \mathrm{g} / \mathrm{g}$ for $546 \mathrm{Co}, \mathrm{Cu}$ and $\mathrm{Cr}$; $1,000 \mu \mathrm{g} / \mathrm{g}$ for $\mathrm{Ni}, \mathrm{Pb}$ and $\mathrm{As} ; 3,000 \mu \mathrm{g} / \mathrm{g}$ for $\mathrm{Zn}$; and 10,000 $\mu \mathrm{g} / \mathrm{g}$ for $\mathrm{Mn}$, 547 with plants growing in their natural habitats. If these criteria are adopted more than 500

548 plant taxa have been cited in the literature to date as hyperaccumulators of one or more 549 elements (As, $\mathrm{Cd}, \mathrm{Co}, \mathrm{Cu}, \mathrm{Mn}, \mathrm{Ni}, \mathrm{Pb}, \mathrm{Se}, \mathrm{Tl}, \mathrm{Zn}$ ). This still represents a very small 550 proportion of the (approximately) 300,000 recognized vascular plant species (The Plant 551 List 2011). Approximate numbers for various elements are as follows: $\mathrm{Ni}$ (450), $\mathrm{Cu}(32)$, 552 Co (30), Se (20), Pb (14), Zn (12), Mn (12), As (5), Cd (2), Tl (2). These numbers are 553 subject to change, and may increase with further exploration and analysis. Some of the 554 tentatively identified hyperaccumulators, particularly those of $\mathrm{Cu}, \mathrm{Co}$, or $\mathrm{Pb}$, might also 555 be removed from the list after further testing (for example in glasshouse experiments in 556 which airborne contamination can be eliminated). It has been suggested that the 557 preponderance of $\mathrm{Ni}$ plants is the result of a greater effort made into seeking these, but 558 there is a more fundamental reason: the total area of Ni-rich ultramafic soils exposed 559 worldwide is much greater than that presented by exposures of the other metals listed.

561 Experiments using hydroponic cultures and metal-amended soils

Baker and Whiting (2002) warn that "In their enthusiasm to report new hyperaccumulator plants, many authors have regularly assumed that if a normally non-accumulating plant can take up $>10,000 \mu \mathrm{g} / \mathrm{g} \mathrm{Zn}$ from hydroponic culture it can be assigned hyperaccumulator status." It must be recognized that almost any plant can do this, but the 'forced' or 'induced' metal uptake often leads ultimately to plant mortality, and may have no relevance to the continuing life cycle of naturally occurring metallophyte populations, even though it may be of interest for some phytoremediation strategies. Many pieces of published experimental work have used metal-amended nutrient solutions containing amendments far in excess of the metal concentrations found in natural soil solution. Such experiments can be useful in demonstrating the tolerance of a species to a particular element, and in showing the fate within the plant of such massive exposure (e.g. how much becomes immobilized within the root system and how much is translocated to the shoots), but have very limited relevance to the natural environment in which the species evolved: the experiments are almost never taken so far as to demonstrate survival and production of viable seed.

580

The problem thus lies in that hydroponic experiments often use unrealistically high dose treatments, where the characteristic differences between hyperaccumulators and non- 
accumulators tend to disappear, because of saturation of the root-to-shoot translocation in

582 the hyperaccumulator, or of the root's sequestration capacity in the non-accumulator.

583 When used sensibly, it seems that hydroponic experiments can help to distinguish

584 genuine hyperaccumulators, provided that the exposure levels are kept low (e.g. $<1 \mu \mathrm{M}$ ).

585 However, experimental confirmation using the natural soil is more straightforward and 586 therefore preferable.

588 Similar comments apply to experiments in which one of the standard soil media is

589 supplemented ('spiked') by the addition of large concentrations of soluble metal salts

590 (nitrates, sulfates, etc.). The nature of the interaction between the amending solution and

591 the base soil is generally largely unknown, and the resulting medium is unlikely to mimic

592 a real metalliferous soil. This is analogue to artificial acidification of natural soil to

593 increase metal-uptake (even if induced phytotoxicity is kept relatively low). Again great

594 care needs to be taken in interpreting (and extrapolating from) the results of such

595 experiments. In both cases, hydroponics and amended or acidified soils, we reject such

596 experiments as capable of defining a species as a hyperaccumulator. Even when natural

597 metalliferous soils are used, large-scale experimental screening for hyperaccumulators

598 could yield misleading results if non-tolerant species are tested. When the tolerance limits

599 of excluder species are exceeded, it is common to observe non-specific 'breakthrough' of

600 metals into the shoot (Fig. 1; Baker 1981), yet this is not hyperaccumulation if the uptake

601 results in death of the plant.

602

603 Hyperaccumulator databases

604

605 In order to provide a univocal platform for sharing knowledge of hyperaccumulators it is

606 proposed to create an online database portal. Attempts to produce such databases have

607 been few and global coverage is patchy. The most well known are Environment Canada's

608 PHYTOREM database and the METALS (metal-accumulating plants) database originally 609 maintained by the Environmental Consultancy, University of Sheffield (now ECUS Ltd, 610 UK). Since 2009, the on-line Global Metallophyte Database (www.metallophytes.com), 611 under the auspices of the International Serpentine Ecology Society (ISES) and future

612 administration by the Centre for Mined Land Rehabilitation (CMLR) of The University 613 of Queensland (UQ), has been put in place and aims to provide a global database 614 available through the internet.

615

616 Conclusions

617

618 The use of the term 'hyperaccumulator' and the theoretical and practical implications of 619 different methods of establishing 'hyperaccumulation status' have been evaluated 620 critically, and we conclude the following as guidelines for future use of the term: 
(1) Nominal threshold criteria currently provide the only practical operational framework for recognizing hyperaccumulators until appropriate physiological definitions are defined in the future. When used sensibly, nominal criteria can guide the identification of extreme physiological behaviour. Furthermore, they are the only way to recognize hyperaccumulators in the field, without experimental cultivation, which has never been attempted for most reported hyperaccumulators.

(2) Hyperaccumulation for nickel, zinc, cadmium, manganese, arsenic and selenium have been confirmed experimentally beyond doubt in a range of plant species.

(3) Hyperaccumulation of lead, copper, cobalt, chromium and thallium have not (yet) been demonstrated beyond doubt in one or more plant species, whereas the use of the term for rare-earth elements requires critical evaluation.

(4) Only plant leaves (or fronds) are to be considered in establishing hyperaccumulator status. Moreover, only metal or metalloids inside plant leaves indicates active (hyper)accumulation. Passive accumulation via air-borne deposition on plant leaves is not to be regarded as hyperaccumulation. Such contamination is a major cause of erroneous designation, particularly for $\mathrm{Pb}$ and Cr.

(5) Growing plants from seed in their natural soil in the glasshouse or climate room is the most appropriate method for confirming hyperaccumulator status. This approach avoids airborne contamination and other uncontrolled irregularities of natural conditions in the field.

(6) Hydroponic experiments often use unrealistically high dose treatments, which can result in spurious claims for supposed hyperaccumulation when 'normal' plants are exposed, resulting in immediate high shoot metal concentrations but also in inevitable plant death.

(7) When exposure levels are kept low hydroponic experiments however can help to distinguish genuine hyperaccumulators by confirming characteristic traits such as hypertolerance to phytotoxic metal ions, hyperaccumulation in the shoot, high bioconcentration factors and high shoot/root metal translocation, and have been an effective methodology for physiological experimentation.

(8) Experimental confirmation using natural soil is preferable over hydroponics, but the use of standard soil 'spiked' with soluble metal salts is unlikely to mimic natural metal-rich soils.

(9) Hydroponics, metal-amended 'spiked' soils and artificially acidified (natural) soils in isolation are not capable of defining a species as a hyperaccumulator: natural populations must be studied.

(10) Critical review suggests that criteria which have been commonly used to delimit hyperaccumulation of some metals are unnecessarily conservative. We propose that the criteria for hyperaccumulation of $\mathrm{Se}$ and $\mathrm{Tl}$ be lowered to $100 \mu \mathrm{g} / \mathrm{g}$ dried 


\section{References}

Anderson C, Brooks R, Chiarucci A, LaCoste C, Leblanc M, Robinson B, Simcock R, Stewart R (1999) Phytomining for nickel, thallium and gold. J Geochem Explor 67:407-

673 Assunção AGL, Bookum WM, Nelissen HJM, Vooijs R, Schat H, Ernst WHO (2003)

674 Differential metal-specific tolerance and accumulation patterns among Thlaspi 675 caerulescens populations originating from different soil types. New Phytol 159:411-419

676 Azcue, JM (1996) Comparison of different cleaning procedures of root material for 677 analysis of trace elements. Int J Environ Anal Chem 62, 2:137-146

678 Baker AJM (1981) Accumulators and excluders - strategies in the response of plants to 679 heavy metals. J Plant Nutr 3:643-654

680 Baker AJM, Brooks RR (1989) Terrestrial higher plants which hyperaccumulate metallic 681 elements - a review of their distribution, ecology and phytochemistry. Biorecovery 1:81$682 \quad 126$

683 Baker AJM, McGrath SP, Sidoli CMD, Reeves RD (1994a) The possibility of in situ 684 heavy metal decontamination of soils using crops of metal-accumulating plants. Resour 685 Conserv Recyc 11:41-49

686 Baker AJM, Reeves RD, Hajar ASM (1994b) Heavy metal accumulation and tolerance in

687 British populations of the metallophytes Thlaspi caerulescens J. and C. Presl 688 (Brassicaceae). New Phytol 127:61-68

689 Baker AJM, Whiting SN (2002) In search of the Holy Grail - a further step in 690 understanding metal hyperacumulation. New Phytol 155:1-7

691 Barillas JRV, Quinn CF, Pilon-Smits EAH (2011) Selenium accumulation in plants 692 phytotechnological applications and ecological implications. Int J Phytorem 13 693 (Supplement 1):166-178

694 Barry SAS, Clark SC (1978) Problems of interpreting the relationship between the 695 amounts of lead and zinc in plants and soil on metalliferous wastes. New Phytol 81:773$696 \quad 783$

697 Becquer T, Quantin C, Sicot M, Boudot J (2003) Chromium availability in ultramafic 698 soils from New Caledonia. Sci Total Environ 301:251-261 
699 Bert V, Bonnin I, Saumitou-Laprade P, De Laguérie P, Petit D (2002) Do Arabidopsis

700 halleri from nonmetallicolous populations accumulate zinc and cadmium more

701 effectively than those from metallicolous populations? New Phytol 155:47-57

702 Bert V, Meerts P, Saumitou-Laprade P, Salis P, Gruber W, Verbruggen N (2003) Genetic

703 basis of $\mathrm{Cd}$ tolerance and hyperaccumulation in Arabidopsis halleri. Plant Soil 249:9-18

704 Broadley MR, Willey NJ, Wilkins JC, Baker AJM, Mead A, White PJ (2001)

705 Phylogenetic variation in heavy metal accumulation in angiosperms. New Phytol 152:9-

$706 \quad 27$

707 Broadley MR, White PJ, Hammond JP, Zelko I, Lux A (2007) Zinc in plants. New Phytol $708 \quad 173: 677-702$

709 Brooks RR (1972) Geobotany and biogeochemistry in mineral exploration. Harper and

710 Row, New York

711 Brooks RR (1987) Serpentine and its vegetation: a multidisciplinary approach.

712 Dioscorides Press, Portland OR

713 Brooks RR (1998) Biogeochemistry and hyperaccumulators. In: Brooks RR (ed) Plants

714 that hyperaccumulate heavy metals. CAB International, Wallingford UK, pp 95-118

715 Brooks RR, Wither, ED (1977) Nickel accumulation by Rinorea bengalensis (Wall.)

716 O.K. J Geochem Explor 7:295-300

717 Brooks RR, Lee J, Reeves RD, Jaffré T (1977) Detection of nickeliferous rocks by

718 analysis of herbarium specimens of indicator plants. J Geochem Explor 7:49-57

719 Brooks RR, McCleave JA, Schofield EK (1977) Cobalt and nickel uptake by the

720 Nyssaceae. Taxon 26:197-201

721 Brooks RR, Radford CC (1978) Nickel accumulation by European species of the genus

722 Alyssum. Proc Roy Soc Lond B 200:217-224

723 Brooks RR, Wither, ED, Westra LYT (1978) Biogeochemical copper anomalies on

724 Salajar Island Indonesia. J Geochem Explor 10:181-188

725 Brooks RR, Morrison RS, Reeves RD, Dudley TR, Akman Y (1979) Hyperaccumulation

726 of nickel by Alyssum Linnaeus (Cruciferae). Proc Roy Soc Lond B 203:387-403

727 Brooks RR, Reeves RD, Morrison RS, Malaisse F (1980) Hyperaccumulation of copper

728 and cobalt - a review. Bull Soc Roy Bot Belg 113:166-172

729 Brooks RR, Grégoire J, Madi L, Malaisse F (1982) Phytogéochimie des gisements cupro-

730 cobaltifères de l'anticlinal de Kasonta (Shaba-Zaïre). Géo-Eco-Trop 6:219-228

731 Brooks RR, Malaisse F (1985) The heavy metal-tolerant flora of southcentral Africa.

732 Balkema, Rotterdam

733 Chaney RL, Brown SL, Li Y-M, Angle JS, Stuczynski TI, Daniels WL, Henry CL,

734 Siebielec G, Malik M, Ryan JA, Compton H (2002) Progress in risk assessment for soil

735 metals, and in-situ remediation and phytoextraction of metals from hazardous

736 contaminated soils. In: Proc. USEPA Conf. 'Phytoremediation: State of the Science.' 1-2

737 May 2000, Boston, MA. USEPA, Washington, DC 
738 Chaney RL, Angle JS, Broadhurst CL, Peters CA, Tappero RV, Sparks DL (2007)

739 Improved understanding of hyperaccumulation yields commercial phytoextraction and

740 phytomining technologies. J Environ Qual 36: 1429-1443

741 Clemens S, Palmgren, MG, Krämer U (2002) A long way ahead: understanding and

742 engineering plant metal accumulation. Trends Plant Sci. 7:309-315

743 Cole MM, Provan DMJ, Tooms JS (1968) Geobotany, biogeochemistry and

744 geochemistry in the Bulman-Waimuna Springs area, Northern Territory, Australia, Trans.

745 Inst. Min. Metall. Sec. B 77, 81-104.

746 Courbot M, Willems G, Motte P, Arvidsson S, Roosens N, Saumitou-Laprade P,

747 Verbruggen N (2007) A major quantitative trait locus for cadmium tolerance in

748 Arabidopsis halleri colocalizes with HMA4, a gene encoding a heavy metal ATPase.

749 Plant Physiol 104:1052-1065

750 Deng D-M, Deng J-C, Li J-T, Zhang J, Hu M, Lin Z, Liao B (2008) Accumulation of

751 zinc, cadmium, and lead in four populations of Sedum alfredii growing on lead/zinc mine

752 spoils. J Integr Plant Biol 50:691-698

753 Deram A, Petit D (1997) Ecology of bioaccumulation in Arrhenatherum elatius L.

754 (Poaceae) populations - applications of phytoremediation of zinc, lead and cadmium

755 contaminated soils. J Exp Bot 48 (Special Supplement): 98

756 Dunn CE (2007) New perspectives on biogeochemical exploration. Paper 12. Advances

757 in prospect-scale geochemical methods. In: Milkereit B (ed) Proceedings of Exploration

758 07: Fifth decennial international conference on mineral exploration, pp 249-261

759 Ernst, WHO (2006) Evolution of metal tolerance in higher plants. For Snow Landsc Res

$76080,3: 251-274$

761 Escarré J, Lefèbvre C, Gruber W, Leblanc M, Lepart J, Rivière Y, Delay B (2000) Zinc

762 and cadmium accumulation by Thlaspi caerulescens from metalliferous and

763 nonmetalliferous sites in the Mediterranean area: implications for phytoremediation. New

764 Phytol 145:429-437

765 Escarré J, Lefèbvre C, Raboyeau S, Dossantos A, Gruber W, Cleyet Marel JC, Frérot H,

766 Noret N, Mahieu S, Collin C, Oort F (2011) Heavy metal concentration survey in soils

767 and plants of the Les Malines mining district (southern France): implications for soil

768 restoration. Water Air Soil Poll 216:485-504

769 Faucon M-P, Shutcha, MN, Meerts P (2007) Revisiting copper and cobalt concentrations

770 in supposed hyperaccumulators from SC Africa: influence of washing and metal

771 concentrations in soil. Plant Soil 301:29-36

772 Feng MH, Shan XQ, Zhang S, Wen B (2005) A comparison of the rhizosphere-based

773 method with DTPA, EDTA, $\mathrm{CaCl}_{2}$, and $\mathrm{NaNO}_{3}$ extraction methods for prediction of

774 bioavailability of metals in soil to barley. Environ Pollut 137:231-240

775 Fernando DR, Woodrow IE, Jaffré T, Dumontet V, Marshall AT, Baker AJM (2008)

776 Foliar manganese accumulation by Maytenus founieri (Celastraceae) in its native New 
777 Caledonian habitats: populational variation and localization by X-ray microanalysis. New

778 Phytol 177:178-185

779 Fernando DR, Guymer G, Reeves RD, Woodrow IE, Baker AJM, Batianoff GN (2009)

780 Foliar Mn accumulation in eastern Australian herbarium specimens: prospecting for

781 'new' Mn hyperaccumulators and potential applications in taxonomy. Ann Bot 103:931-

$782 \quad 939$

783 Freeman, JL (2006) Spatial imaging, speciation, and quantification of selenium in the

784 hyperaccumulator plants Astragalus bisulcatus and Stanleya pinnata. Plant Physiol.

785 142:124-34

786 Gao Y, Zhou P, Mao L, Shu W, Ye Z (2010) Phytoextraction of cadmium and 787 physiological changes in Solanum nigrum as a novel cadmium hyperaccumulator. Russ J

788 Plant Physiol 57:501-508

789 Garnier J, Quantin C, Martins E, Becquer T (2006) Solid speciation and availability of

790 chromium in ultramafic soils from Niquelândia, Brazil. J Geochem Explor 88:206-209

791 Han FX, Sridhar BBM, Monts DL, Su Y (2004) Phytoavailability and toxicity of trivalent

792 and hexavalent chromium to Brassica juncea. New Phytol 162:489-499

793 Hanikenne M, Talke IN, Haydon MJ, Lanz C, Nolte A, Motte P, Kroyman J, Weigel D,

794 Krämer U (2008) Evolution of metal hyperaccumulation required cis-regulatory changes

795 and triplication of HMA4. Nature 453:391-395

796 Hobbs RH, Streit B (1986) Heavy metal concentrations in plants growing on a copper 797 mine spoil in the Grand Canyon, Arizona. Am Midl Nat 115:277-281

798 Hoffmann P, Baker AJM, Proctor J, Madulid, DA (2003) Phyllanthus balgooyi

799 (Euphorbiaceae s.l.), a new nickel-hyperaccumulating species from Palawan and Sabah.

800 Blumea 48:193-199

801 Jaffré T (1977) Accumulation du manganese par des especés associés aux terrains

802 ultrabasiques de Nouvelle-Calédonie. C R Acad Sci Paris D 284:1573-1575

803 Jaffré T (1979) Accumulation du manganese par les Protéacées de Nouvelle- Calédonie.

804 C R Acad Sci Paris D 289:425-428

805 Jaffré T (1980) Etude écologique du peuplement végétal des sols dérivés de roches

806 ultrabasiques en Nouvelle-Calédonie. Paris: Travaux et Documents de l'ORSTOM 124.

807 Jaffré T, Schmid M (1974) Accumulation du nickel par une Rubiacée de Nouvelle

808 Calédonie, Psychotria douarrei (G. Beauvisage) Däniker. C R Acad Sci Paris D

809 278:1727-1730

810 Jaffré T, Brooks RR, Lee J, Reeves RD (1976) Sebertia acuminata: a hyperaccumulator

811 of nickel from New Caledonia. Science 193:579-580

812 Jiang L, Yang X, He Z (2004) Growth response and phytoextraction of copper at

813 different levels in soils by Elsholtzia splendens. Chemosphere 55:1179-1187

814 Johnston WR, Proctor J (1977) A comparative study of metal levels in plants from two

815 contrasting lead-mine sites. Plant Soil 46:251-257 
816 Talke IN, Hanikenne M, Krämer, U (2006) Zinc-dependent global transcriptional control, 817 transcriptional deregulation, and higher gene copy number for genes in metal homeostasis 818 of the hyperaccumulator Arabidopsis halleri. Pl Physiol 142:148-167

819 Krämer U, Smith RD, Wenzel WW, Raskin I, Salt DE (1997) The role of metal transport

820 and tolerance in nickel hyperaccumulation by Thlaspi goesingense Halácsy. Pl Physiol $821 \quad 115: 1641-1650$

822 Krämer U (2010) Metal hyperaccumulation in plants. Ann Rev Plant Biol 61:517-534

823 Kubota J, Lazar VA, Beeson, KC (1960) The study of cobalt status of soils in Arkansas 824 and Louisiana using the black gum as the indicator plant. Soil Science Proceedings 24: $825 \quad 527-528$

826 Kumar PBAN, Dushenkov V, Motto H, Raskin I (1995) Phytoextraction: the use of 827 plants to remove heavy metals from soils. Environ Sci Technol 29:1232-1238

828 LaCoste C, Robinson BH, Brooks RR, Anderson CWN, Chiarucci A, Leblanc M (1999)

829 The phytoremediation potential of thallium-contaminated soils using Iberis and 830 Biscutella species. Int J Phytorem 1:327-338

831 Lai Y, Wang Q, Yang L, Huang B (2006) Subcellular distribution of rare earth elements

832 and characterization of their binding species in a newly discovered hyperaccumulator

833 Pronephrium simplex. Talanta 70:26-31

834 Leblanc M, Petit D, Deram A, Robinson BH, Brooks RR (1999) The phytomining and 835 environmental significance of hyperaccumulation of thallium by Iberis intermedia from 836 southern France. Econ Geol 94:109-113

837 Leteinturier B (2002) Evaluation du potential phytocénotique des gisements cuprifères 838 d'Afrique centro-australe en vue de la phytoremédiation de sites pollués par 839 l'activitéminière. PhD Thesis, Faculté des Sciences Agronomiques de Gembloux, 840 Belgium

841 Li J-T, Deng DM, Peng GT, Deng JC, Zhang J, Liao B (2010) Successful 842 micropropagation of the cadmium hyperaccumulator Viola baoshanensis (Violaceae). Int 843 J Phytorem 12:761-771

844 Liu W, Shu W, Lan C (2004) Viola baoshanensis, a plant that hyperaccumulates 845 cadmium. Chinese Sci Bull 49:29-32

846 Lombi E, Zhao FJ, Dunham SJ, McGrath SP (2000) Cadmium accumulation in 847 populations of Thlaspi caerulescens and Thlaspi goesingense. New Phytol 145:11-20

848 Lombi E, Zhao F, McGrath S, Young S, Sacchi G (2001) Physiological evidence for a 849 high-affinity cadmium transporter highly expressed in a Thlaspi caerulescens ecotype.

850 New Phytol 149:53-60

851 Ma LQ, Komar KM, Tu C, Zhang W, Cai Y and Kennelley ED (2001) A fern that 852 hyperaccumulates arsenic. Nature 409:579.

853 Macnair M (2003) The hyperaccumulation of metals by plants. Adv Bot Res 40:63-105

854 Malaisse F, Grégoire J, Brooks RR, Morrison RS, Reeves RD (1978) Aeolanthus

855 biformifolius: a hyperaccumulator of copper from Zaïre. Science 199:887-888

856 Malik M, Chaney RL, Brewer EP, Angle JS (2000) Phytoextraction of soil cobalt using 
857 hyperaccumulator plants. Int J Phytorem 2:319-329

858 Markert B (1994) Progress report on the element concentrations cadastre project (ECCP)

859 of INTERCOL/IUBS, International Union of Biological Sciences, 25th General

860 Assembly, Paris

861 McGrath SP (1998) Phytoextraction for soil remediation. In: Brooks RR (ed) Plants that

862 hyperaccumulate heavy metals. CAB International, Wallingford UK, pp 261-287

863 McLaughlin BE, Loon GW, Crowder AA (1985) Comparison of selected washing 864 treatments on Agrostis gigantea samples from mine tailings near Copper Cliff, Ontario, 865 before analysis for $\mathrm{Cu}, \mathrm{Ni}, \mathrm{Fe}$ and $\mathrm{K}$ content. Plant Soil. 85, 3: 433-436

866 Metali F, Salim KA, Burslem DFRP (2012) Evidence of foliar aluminium accumulation 867 in local, regional and global datasets of wild plants. New Phytol 193:637-649

868 Mohtadi A, Ghaderian SM, Schat H (2012) A comparison of lead accumulation and 869 tolerance among heavy metal hyperaccumulating and non-hyperaccumulating 870 metallophytes. Plant Soil 352, 1-2:267-276

871 Nowack, B, Schulin, R, Robinson, BH (2006) Critical assessment of chelant-enhanced 872 metal phytoextraction. Environ Sci Technol 40: 5225-5232.

873 Pence NS, Larsen PB, Ebbs SD, Letham DLD, Lasat MM, Garvin DF, Eide D, Kochian 874 LV (2000) The molecular physiology of heavy metal transport in the $\mathrm{Zn} / \mathrm{Cd}$ 875 hyperaccumulator Thlaspi caerulescens. Proc Nat Acad Sci USA 97:4956-4960

876 Pollard AJ, Powell KD, Harper FA, Smith JAC (2002) The genetic basis of metal 877 hyperaccumulation in plants. Crit Rev Plant Sci 21:539-566

878 Pollard AJ, Stewart HS, Roberson CB (2009) Manganese hyperaccumulation in 879 Phytolacca americana L. from the Southeastern United States. Northeast Nat 16:155-162 880 Rajakaruna N, Baker AJM (2006) Serpentine: a model habitat for botanical research in 881 Sri Lanka. Ceylon J Sci 32:1-19

882 Redondo-Gomez S, Mateos-Naranjo E, Vecino-Bueno, I, Feldman SR (2011) 883 Accumulation and tolerance characteristics of chromium in a cordgrass Cr884 hyperaccumulator, Spartina argentinensis. J Haz Mater 185:862-869

885 Reeves RD (1988) Nickel and zinc accumulation by species of Thlaspi L., Cochlearia L., 886 and other genera of the Brassicaceae. Taxon 37:309-318

887 Reeves RD (1992) Hyperaccumulation of nickel by serpentine plants. In: Baker AJM, 888 Proctor J, Reeves RD (eds) The vegetation of ultramafic (serpentine) soils. Intercept, 889 Andover UK, pp 253-277

890 Reeves RD, Schwartz C, Morel JL, Edmondson J (2001) Distribution and metal891 accumulating behavior of Thlaspi caerulescens and associated metallophytes in France.

892 Int J Phytorem 3:145-172

893 Reeves RD (2003) Tropical hyperaccumulators of metals and their potential for 894 phytoextraction. Plant Soil 249:57-65

895 Reeves RD (2005) Hyperaccumulation of trace elements by plants. In: Morel J-L, 896 Echevarria G, Goncharova N (eds) Phytoremediation of metal-contaminated soils, 897 Proceedings of the NATO Advanced Study Institute, Třešt' Castle, Czech Republic, 18- 
89830 August 2002. NATO Science Series: IV: Earth and Environmental Sciences 68. 899 Springer, Berlin, pp 25-52

900 Reeves RD, Brooks RR (1983a) European species of Thlaspi L. (Cruciferae) as indicators 901 of nickel and zinc. J Geochem Explor 18:275-283

902 Reeves RD, Brooks RR (1983b) Hyperaccumulation of lead and zinc by two 903 metallophytes from a mining area in Central Europe. Environ Pollut 31:277-287

904 Reeves RD, Baker AJM, Borhidi A, Berazaín R (1996) Nickel-accumulating plants from 905 the ancient serpentine soils of Cuba. New Phytol 133:217-224

906 Reeves RD, Baker AJM (2000) Metal-accumulating plants. In: Raskin I, Ensley BD (eds)

907 Phytoremediation of toxic metals: using plants to clean up the environment. Wiley, New 908 York, pp 193-229

909 Reeves RD, Schwartz C, Morel JL, Edmondson J (2001) Distribution and metal910 accumulating behavior of Thlaspi caerulescens and associated metallophytes in France. 911 Int J Phytorem 3:145-172

912 Reeves RD, Ma RL, McLeod CW (2005) Lead isotope composition of some European 913 mine and smelter soils and a possible application to hyperaccumulation studies. In: 914 Abstracts of the 8th International Conference on the Biogeochemistry of Trace Elements, 915 Adelaide, Australia, April 2005, pp 448-449

916 Reeves RD, Baker AJM, Bequer T, Echevarria G, Miranda ZJC (2007) The flora and 917 biogeochemistry of the ultramafic soils of Goiás state, Brazil. Plant Soil 293:107-119

918 Richau KH, Kozhevnikova AD, Seregin IV, Vooijs R, Koevoets PLM, Smith JAC, 919 Ivanov VB, Schat H (2009) Chelation by histidine inhibits the vacuolar sequestration of 920 nickel in roots of the hyperaccumulator Thlaspi caerulescens. New Phytol 183:106-116

921 Robinson BH, Leblanc M, Petit D, Brooks RR, Kirkman JH, Gregg PEH (1998) The 922 potential of Thlaspi caerulescens for phytoremediation of contaminated soils. Plant Soil $923 \quad 203: 47-56$

924 Robinson BH, Brooks, RR, Hedley MJ (1999) Cobalt and nickel accumulation in Nyssa 925 (tupelo) species and its significance for New Zealand agriculture. NZ J Agric Res 42: $926 \quad 235-240$

927 Robinson BH, Kim N, Marchetti M, Moni C, Schroeter L, van den Dijssel C, Milne G, 928 Clothier B (2006) Arsenic hyperaccumulation by aquatic macrophytes in the Taupo 929 Volcanic Zone, New Zealand. Environ Exp Botany 58:206-215

930 Ro $\square$ mkens P, Bouwman L, Japenga J, Draaisma C (2001) Potentials and drawbacks of 931 chelate-enhanced phytoremediation of soils. Environ Pollut 116:109-121

932 Roosens N, Verbruggen N, Meerts P, Ximénez-Embún P, Smith JAC (2003) Natural

933 variation in cadmium tolerance and its relationship to metal hyperaccumulation for seven 934 populations of Thlaspi caerulescens from western Europe. Plant Cell Environ 26:16579351672

936 Rosenfeld I, Beath OA (1964) Selenium - Geobotany, Biochemistry, Toxicity and 937 Nutrition. Academic Press, New York. 
938 Rotkittikhun P, Kruatrachue M, Chaiyarat R, Ngernsansaruay C, Pokethitiyook P, 939 Paijitprapaporn A, Baker AJM (2006) Uptake and accumulation of lead by plants from

940 the Bo Ngam lead mine area in Thailand. Environ Pollut 144:681-688

941 Salt DE, Smith RD, Raskin I (1998) Phytoremediation. Annu Rev Plant Phys Plant Molec

942 Biol 49:643-668

943 Schat, H (1999) Plant responses to inadequate and toxic micronutrient availability:

944 General and nutrient-specific mechanisms. In: Gissel-Nielsen, G.; Jensen, A. (eds) Plant

945 nutrition - molecular biology and genetics. Dordrecht, Kluwer. 311-326

946 Shan XQ, Wang HO, Zhang SZ, Zhou HF, Zheng Y, Yu H, Wen B (2003) Accumulation

947 and uptake of light rare earth elements in a hyperaccumulator Dicranopteris dichotoma.

948 Plant Sci 165:1343-1353

949 Sun Y-B, Zhou Q-X, Ren L-P (2007) Growth responses of the newly-discovered Cd950 hyperaccumulator Rorippa globosa and its accumulation characteristics of $\mathrm{Cd}$ and $\mathrm{As}$ 951 under joint stress of Cd and As. Front Environ Sci Eng China 1:107-113

952 Shen ZG, Zhao FJ, McGrath SP (1997) Uptake and transport of zinc in the 953 hyperaccumulator Thlaspi caerulescens and the non-hyperaccumulator Thlaspi 954 ochroleucum. Plant Cell Environ 20:898-906

955 Swenson U, Munzinger J (2010) Revision of Pycnandra subgenus Sebertia (Sapotaceae) 956 and a generic key to the family in New Caledonia. Adansonia 32:239-249

957 Talke IN, Hanikenne M, Krämer U (2006) Zinc-dependent global transcriptional control, 958 transcriptional deregulation, and higher gene copy number for genes in metal homeostasis 959 of the hyperaccumulator Arabidopsis halleri. Plant Physiol 142:148-167

960 Tandy S, Mundus S, Yngvesson J, Bang TC, Lombi E, Schjoerring JK, Husted S (2011)

961 The use of DGT for prediction of plant available copper, zinc and phosphorus in 962 agricultural soils. Plant Soil 346:167-180

963 Tang Y-T, Qiua R-L, Zeng X-W, Ying R-R, Yu F-M, Zhou X-Y (2009) Lead, zinc,

964 cadmium hyperaccumulation and growth stimulation in Arabis paniculata Franch.

965 Environ Exp Bot 66:126-134

966 Terry N, Zayed AM, de Souza MP, Tarun AS (2000) Selenium in higher plants. Ann 967 Rev Plant Phys Plant Molec Biol 51:401-432

968 The Plant List (2010) Version 1. http://www.theplantlist.org/. Accessed 19 September 9692011

970 Van de Mortel JE, Almar VillAnueva L, Schat H, Kwekkeboom J, Coughlan S, Moerland 971 PD, Ver Loren van Themaat E, Koornneef M, Aarts MGM (2006) Large expression 972 differences in genes for iron and zinc homeostasis, stress response, and lignin 973 biosynthesis distinguish roots of Arabidopsis thaliana and the related metal 974 hyperaccumulator Thlaspi caerulescens. Plant Physiol 142:1127-1147

975 Vassil AD, Kapulnik Y, Raskin I, Salt DE (1998) The role of EDTA in lead transport and 976 accumulation by Indian mustard. Plant Physiol 117:447-453 
977 Visoottiviseth P, Francesconi K, Sridokchan W (2002) The potential of Thai indigenous

978 plant species for the phytoremediation of arsenic contaminated land. Environ Pollut 979 118:453-461

980 Wang H, Shan X-Q, Wen B, Zhang S, Wang Z-J (2004) Responses of antioxidative 981 enzymes to accumulation of copper in a copper hyperaccumulator of Commelina 982 communis. Arch Environ Con Tox 47:1-9

983 Wang H, Wong MH, Lan C, Baker AJM, Qin Y, Chen G, Shu W, Ye ZH (2007) Uptake 984 and accumulation of arsenic by 11 Pteris taxa from southern China. Environ Pollut 985 145:225-233

986 Wang LF, Ji HB, Bai K, Li LB, Kuang TY (2006) Photosystem 2 activities of hyper987 accumulator Dicranopteris dichotoma Bernh. from a light rare earth elements mine. 988 Photosynthetica 44:202-207

989 Wang SL, Liao WB, Lu FQ, Liao B, Shu WS (2009) Hyperaccumulation of lead, zinc 990 and cadmium in plants growing on a lead/zinc outcrop in Yunnan Province, China. 991 Environ Geol 58:471-476

992 Watanabe T, Broadley MR, Jansen S, White PJ, Takada J, Satake K, Takamatsu T, Tuah 993 SJ, Osaki M (2007) Evolutionary control of leaf element composition in plants. New 994 Phytol 174:516-523

995 Watanabe T, Broadley MR, Jansen S, White PJ, Takada J, Satake K, Tandy S, Mundus S, 996 Yngvesson J, Bang TC, Lombi E, Schjoerring JK, Husted S (2011) The use of DGT for 997 prediction of plant available copper, zinc and phosphorus in agricultural soils. Plant Soil 998 346:167-180

999 Wei S, Zhou Q, Koval PV (2006) Flowering stage characteristics of cadmium 1000 hyperaccumulator Solanum nigrum L. and their significance to phytoremediation. Sci 1001 Total Environ 369:441-446

1002 Wei Z, Hong F, Yin M, Li H, Hu F, Zhao G, Wong WJ (2005) Subcellular and molecular 1003 localization of rare earth elements and structural characterization of yttrium bound 1004 chlorophyll a in naturally grown fern Dicranopteris dichotoma. Microchem J 80:1-8

1005 Willems G, Dräger DB, Courbot M, Godé C, Verbruggen N, Saumitou-Laprade P (2007)

1006 The genetic basis of zinc tolerance in the metalllophyte Arabidopsis halleri ssp. halleri 1007 (Brassicaceae): an analysis of quantitative trait loci. Genetics 176:659-674

1008 Williams ST, McNeilly T, Wellington EHM (1977) The decomposition of vegetation 1009 growing on metal mine waste. Soil Biol Biochem 9:271-275

1010 Wu LH, Luo Y-M, Xing XR, Christie P (2004) EDTA-enhanced phytoremediation of 1011 heavy metal-contaminated soil with Indian mustard and associated potential leaching 1012 risk. Agric Ecosyst Environ 102:307-318.

1013 Wu C, Liao B, Wang S-L, Zhang J, Li J-T (2010) Pb and Zn accumulation in a Cd1014 hyperaccumulator (Viola baoshanensis). Int J Phytoremediat 12:574-585 
1015 Xue SG, Chen YX, Reeves RD, Baker AJM, Lin Q, Fernando DR (2004) Manganese 1016 uptake and accumulation by the hyperaccumulator plant Phytolacca acinosa Roxb. 1017 (Phytolaccaceae). Environ Pollut131:393-399

1018 Zhang H, Lombi E, Smolders E, McGrath S (2004) Kinetics of Zn release in soils and 1019 prediction of $\mathrm{Zn}$ concentration in plants using diffusive gradients in thin films. Environ 1020 Sci Technol 38:3608-3613

1021 Zhang XH, Liu J, Huang HT, Chen J, Zhu Y, Wang DQ (2007) Chromium accumulation 1022 by the hyperaccumulator plant Leersia hexandra Swartz. Chemosphere 67:1138-1143.

1023 Zhao FJ, Hamon RE, Lombi E, McLaughlin MJ, McGrath SP (2002) Characteristics of 1024 cadmium uptake in two contrasting ecotypes of the hyperaccumulator Thlaspi 1025 caerulescens. J Exp Bot 53:535-543

1026 


\section{CAPTION FOR FIGURE 1}

1028

1029 Conceptual response diagram for uptake of metals and metalloids in plant leaves/fronds,

1030 adapted from Baker (1981). 'Normal' plants can only tolerate low concentrations of

1031 bioavailable metals/metalloids in soil, before they die due to acute phytotoxicity.

1032 Excluders however can grow over a wide range of phytotoxic available metals before

1033 physiological mechanisms cannot control and allow unregulated uptake, resulting in

1034 death of the plant. Bioindicators take up metals over a wider range than 'normal' plants

1035 and the concentrations in plant leaves reflect that of the soil, until phytotoxicity prevents

1036 further growth and causes death of the plant. Hyperaccumulators are able to withstand

1037 much higher concentrations of bioavailable metals than 'normal' plants, bioindicators

1038 and excluders, and because of competitive disadvantages and greater sensitivity to fungal

1039 and pathogen infections, most do not occur over non-metal-enriched soils, depicted by

1040 the latent start of the line in the diagram. The dotted baseline indicates the

1041 hyperaccumulator threshold for the different metals and metalloids: $100 \mu \mathrm{g} / \mathrm{g}$ for $\mathrm{Cd}$, Se

1042 and $\mathrm{Tl}, 300 \mu \mathrm{g} / \mathrm{g}$ for $\mathrm{Cu}$, Co and Cr, $1000 \mu \mathrm{g} / \mathrm{g}$ for $\mathrm{Ni}, \mathrm{As}$, and Pb, $3000 \mu \mathrm{g} / \mathrm{g}$ for Zn, and

$104310,000 \mu \mathrm{g} / \mathrm{g}$ for Mn. Note that the response line for hyperaccumulators represents the

1044 possible behaviour of such plants, individual plant concentrations are scattered around

1045 the line, and most hyperaccumulators occupy only a small portion of the line (above the

1046 hyperaccumulation threshold).

1047 


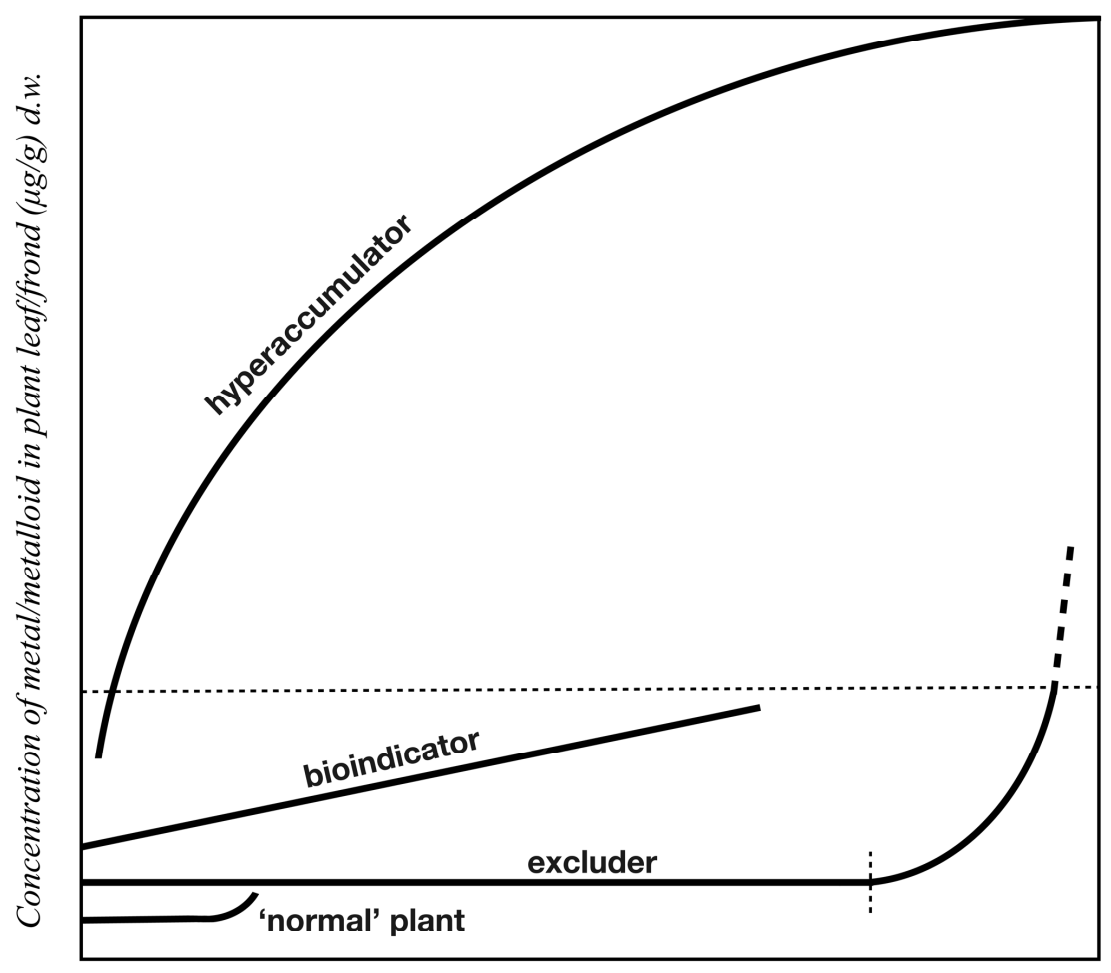

Plant available metal/metalloid concentration in soil 


\section{University Library}

\section{- M M N E R VA A gateway to Melbourne's research publications}

Minerva Access is the Institutional Repository of The University of Melbourne

Author/s:

van der Ent, A;Baker, AJM;Reeves, RD;pollard, AJ;Schat, $\mathrm{H}$

Title:

Hyperaccumulators of metal and metalloid trace elements: Facts and fiction

Date:

2013-01-01

Citation:

van der Ent, A., Baker, A. J. M., Reeves, R. D., pollard, A. J. \& Schat, H. (2013).

Hyperaccumulators of metal and metalloid trace elements: Facts and fiction. PLANT AND SOIL, 362 (1-2), pp.319-334. https://doi.org/10.1007/s11104-012-1287-3.

Persistent Link:

http://hdl.handle.net/11343/282990 